\section{STORAGE RESERVOIRS AS A FACTOR IN THE PURIFICATION OF SURFACE WATERS ${ }^{1}$}

\author{
BY S. T. POWELL
}

The impounding of surface waters in storage reservoirs has been practiced for years, but the primary object of such treatment has been the conservation of the supplies or the physical improvements to the water to be derived from sedimentation. Until within a few years past very little was known concerning the hygienic improvement that takes place in water retained in storage basins. Dr. Sedgwick ${ }^{2}$ made note of this fact in a paper which he read before the New England Water Works Association. $\mathrm{He}$ pointed out that it was but fifteen years ago that he advanced the theory that it was in "stagnant" rather than in runing water that the greatest bacteriological purification takes place. At that time this statement caused considerable discussion on account of this seemingly radical theory. Since that time so much has been learned concerning the chemical and bacterial efficiency of storage reservoirs that it is improbable that any sanitarian would attempt to disprove this general statement.

For a time a number of cities in this country depended wholly upon this method of purification but, as stated by $\mathrm{Mr}$. George W. Fuller," "this method is expensive and seldom tried at present." With our present knowledge of water treatment, aside from the economic standpoint, it is doubtful if the public would be content with this form of purification as a complete or sufficiently safe one. Considered merely as an adjunct to filtration or sterilization preliminary to such treatment, storage reservoirs are particularly efficient and the purification to be derived in this way far outweighs certain disadvantages that are at times encountered in the course of storage. It is in respect to a consideration of the value of stored water as a preliminary method of purification prior to ozone sterilization that it is dealt with in this paper.

During the past fifteen, months the writer has been afforded an opportunity to study conditions in the Herring Run storage reservoirs used in connection with the ozone plant of the Baltimore County Water and Electric Company. The raw water supply is obtained from Herring Run, a small stream which flows through a rather thickly populated district in Baltimore County adjacent to Baltimore City.

Previous to ozonization the raw water is stored in two shallow reservoirs holding approximately eighty million $(80,000,000)$ gallons, permitting about a 3 -weeks storage period. These reservoirs are used in tandem, the water flowing from the first to the second basin through an outlet chamber with gates at different levels so as to draw the water from near the surface at all times. Since undertaking a study of conditions that exist in these reservoirs weekly samples of the raw water and of the effluent have been made. The results obtained, particularly the bacterial data, are

1 Presented at the $53 \mathrm{rd}$ Meeting of the American Chernical Society, New York City, September 25 to $30,1916$.

2 Dr. Wm. T. Sedgwick, "Water Supply Sanitation in the Nineteenth and Twentieth Centuties," N.E. W,W. Assoc, 1916.

3 Geo. W. Fuller, "The Purification of Water from Standpoints Other than the Hygienic Aspect," Trans. 15th Congr. Hyg. and Demography, 1912. of unusual interest, considering the fact that the reservoirs are quite shallow, averaging probably less than Io ft. in depth, and that the period of storage does not exceed 3 weeks.

The physical and chemical improvement to the water passing through these basins has been quite marked at all seasons of the year, but these removals have in no sense been abnormal. There has been an average reduction in turbidity of 14.2 per cent during the period covered by these tests, with a maximum removal of 35.3 per cent during July, I9I5. The efficiency of storage here in respect to the removal of turbidity has not been as great as at other places with the same detention period. This is due to the fact that during periods of high water, when the raw supply contains the greatest amount of suspended solids, the influent gates have been closed and the necessary daily pumpage has been drawn from storage. The removal of the color effected by these reservoirs has been marked, averaging $\mathrm{I} 5.0$ per cent, but contrary to expectation the greatest color reductions have been in the spring and fall and not during the summer months as has usually been noted by observers in studying the bleaching effect of sunlight upon stored water. The greatest bleaching effect is normally to be obtained during the warmest months of the year, on account of the more active oxidation of the organic coloring matter and by the direct decolorizing effect of the sunlight. Stearns, ${ }^{1}$ in studying these conditions in ten reservoir supplies of Boston, reported color reduction of from 9 to 69.5 per cent for periods of from one to nine years. Low color reductions were claimed by $\mathrm{Mr}$. Stearns to be due to "color absorbed from reservoir beds" and this in a measure offsets the normal decolorization due to storage.

The reason the color reduction has been less here in summer is believed to be due not entirely to the absorption of organic substances in the reservoir bottoms but to the fact that during the summer months the algae growths are always prolific. Many of these growths ${ }^{2}$ are chlorophyll-bearing organisms and, due to disintegration, the chlorophyll is scattered throughout the water and this tends to lessen the bleaching effect of the sunlight. In addition to reduction in color and turbidity there has been consistent removal of organic matter from the water as shown in Table I.

Table I-Showing Percentage Removal of Chemical Constituents DUE TO STORAGE IN THE HERRING RUN RESERVOIR



(a) These determinations have not been made throughout the entire year.

The physical and chemical improvement to be gained by storage cannot be discounted, yet the hygienic betterment derived by the diminution of the

1 Ralph H. Stearns, "Decolorization of Water by Storage," N. E. W. W. Assoc., 1916.

:S. T. Powell, "The Effect of Ozone on Algae Growths," A.W.W. Assoc., 1914. 


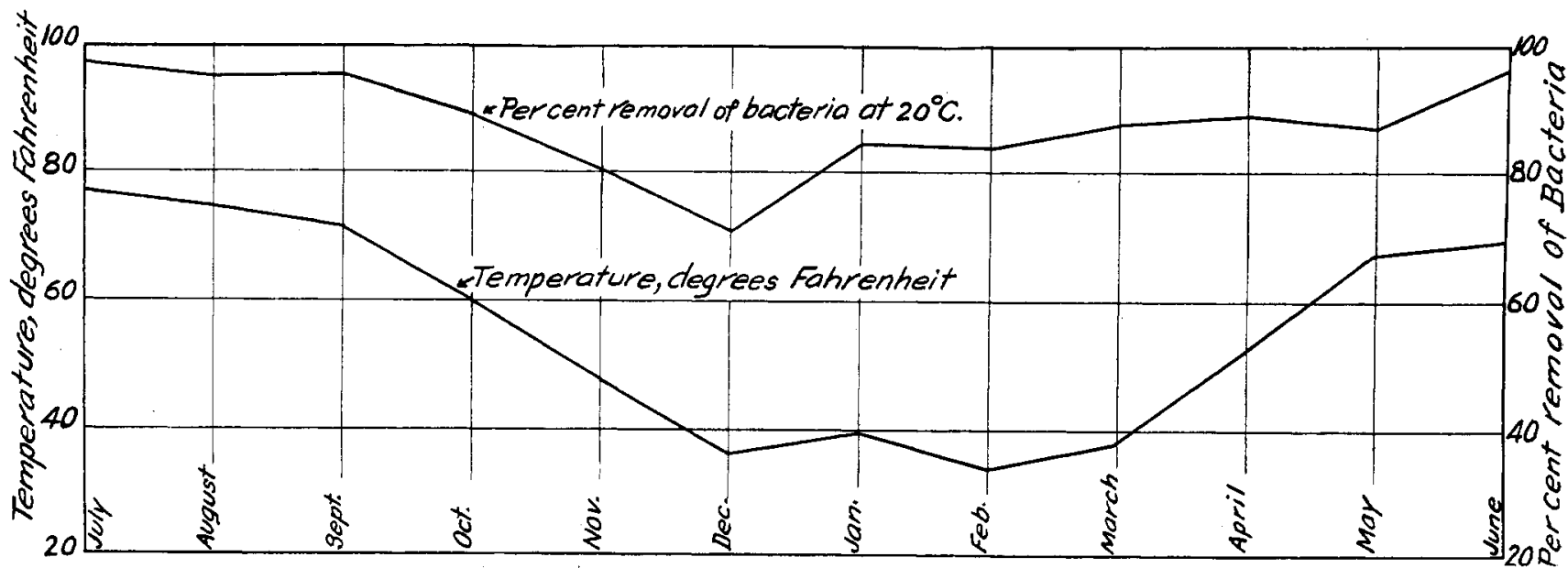

Fig. I-Percentage Removal of $20^{\circ} \mathrm{C}$. Bacteria Effected by Storage Regervolr at Herring Run in Comparison with the Average MONTHLY TFMPERATURES

bacterial count is of far greater value. The careful and exhaustive studies of $\mathrm{Dr}$. A. C. Houston of the Metropolitan Water Board of London has clearly demonstrated the fact that by storage alone a very high percentage of the bacteria can be removed.

The bacterial reduction obtained in the Herring Run reservoirs has been quite high, but the efficiencies have varied with the seasons. There has been a direct relationship between the atmospheric temperature and the efficiency of these reservoirs in the elimination of the bacteria growing at $20^{\circ} \mathrm{C}$. From Fig. I it will be seen that the greatest bacterial removal was during July, when the average temperature was the highest during the year. From then on there was a gradual and uniform falling off in the bacterial efficiency until January, when the sudden rise in temperature was followed immediately by an increased efficiency in the percentage removal of this type of bacterium. It will be noted also from Fig. II that the destruction in the removal of these types was considerably less than for the saprophytic bacteria. This condition has been noted by Houston, ${ }^{1}$ Don and Chisholm ${ }^{2}$ and others, and explained by the fact that in summer the active growth of the saprophytes creates an environment antagonistic to the life of the blood temperature germs. Recently the writer has made series of tests in the laboratory which tend to show that the rate of removal of the $38^{\circ}$ bacteria, and particularly $B$. coli forms, is far more rapid in the presence of active growths of saprophytes than where such organisms are absent from the water.

Numerous theories have been advanced to account for the beneficial effect to surface waters brought about by storage. There is a general consensus of opinion, however, that the purification effected is due to no single catse but to the combined results of equalization, sedimentation and inanition or devitalization of the bacteria. The advisability of retaining surface

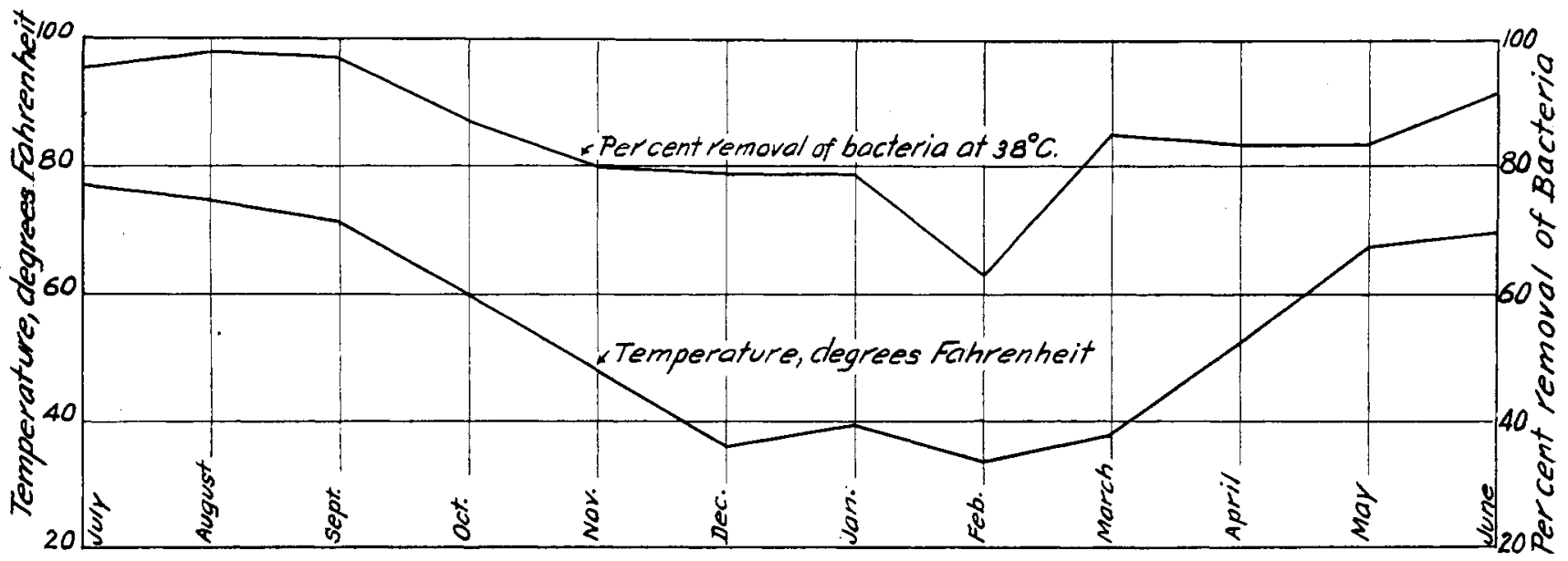

Fig. II-Percentage Removal of $38^{\circ}$ C. Bacteria Effected by Storage Regervolr at Hefring Run in Comparison with the Averaga MONTHLY TEMPERATURES

of $38^{\circ}$ bacteria appears to be less affected by temperature changes than that of the $20^{\circ}$ organisms.

It is interesting to note that during the summer months the percentage removal of blood temperature microbes was greater than $20^{\circ}$ bacteria, but during the colder months the growth of these organisms was more persistent and the efficiency of the reservoirs waters in storage reservoirs to a condition of sterility in respect to the pathogenic bacteria the supplies may contain is an uncertain and questionable procedure

I Dr. A. C. Houston, "The Purification of Water by Storage," Trans. 15th Congr. Hyg. and Demography, 1912. The Eighth Annual Report of the

Metropolitan Water Board of London, 1914.
2 Don and Chisholm, "Modern Methods of Water Purification," 1913. 
from an economic as well as practical viewpoint, but the bacterial reduction produced by comparatively short detention periods prior to final purification by means of filtration or sterilization with chemicals has much to appeal to the practical side of this question. The potent advantages in favor of such preliminary treatment are the reduction of all forms of bacterial life, but particularly the removal to a very large extent of the pathogenic germs, and the general physical and chemical improvements of the water ensuring more uniform control and economical operation of the final purification system, due to the equalizing effect that reservoirs of this type produce.

100 W. Fayette Street

BALTIMORE, MARYLAND

\section{LABORATORY AND PLANT}

\section{AN EXPERIMENT IN THE EDUCATION OF CHEMICAL ENGINEERS 1}

\section{THE TWENTY-FIFTH ANNIVERSARY OF THE AUDUBON SUGAR SCHOOL}

By Charles E. Coates

In these days of preparedness, the training of chemical engineers has taken on a consequence which is interesting both to the college and the country at large. The part which the chemist has played in modern development, we have known in a way for some years, of course, but we are appreciating now as never before, the vital and imperative importance to our nation of a body of men who cannot only discover chemical principles but can also apply them industrially.

At the same time, it has been generally acknowledged that college courses in Chemical Engineering have hitherto been lacking in some essential ingredient. Numerous efforts have been made to remedy this state of affairs. Among the most recent are the industrial fellowship system of the Mellon Institute and the plan lately outlined by the Massachusetts Institute of Technology, accounts of which have appeared in THIS Journal. The English journals are full of new schemes for the training of chemical engineers; indeed practically all the larger schools have changed such courses materially within the past few years. In view of this and inasmuch as experience, after all, is the only safe guide in the jungle of educational theory, it has been thought that a brief sketch of the origin and development of the Audubon Sugar School might not be untimely.

Few people realize how very largely the sugar industry of to-day is a chemical industry. A little over a century ago, when sugar was first made from beets, the root was low in sucrose and the process gave a poor yield of an inferior grade of sugar with an almost valueless molasses. The chemist and the agronomist, working together, slowly raised the sucrose content of the beet root until it was more than doubled; the chemist and engineer, working together, slowly improved the processes until a good yield of sugar was turned out, practically pure, and both the molasses and all the other by-products became sources of profit and not of loss. In consequence the net cost of beet sugar fell year by year until it became a serious competitor of cane sugar and, finally, it was offered at prices closely approaching the cost of cane sugar production.

The sugar planters of Louisiana, as a class, are cer-

1 Presented at the 53rd Meeting of the American Chemical Society, New York City, September 25 to $30,1916$. tainly among the most intelligent agriculturalists in America. Seeing the increasing gravity of the situation, they decided to meet the competition of beet sugar by the same methods which made that competition possible. In the late eighties they called to Louisiana Dr. W. C. Stubbs and established, under his direction, the Sugar Experiment Station at Kenner, Louisiana, which was subsequently moved to Audubon Park, on the outskirts of New Orleans. This station was financed entirely by the planters of Louisiana. A complete sugar house was erected on a scale large enough to give commercial results, and altogether, perhaps $\$ 100,000$ worth of equipment was obtained either by purchase or gift.

As soon as the work was fairly under way, it became evident that there were many leaks in the sugar industry as carried on in Louisiana and that these could be stopped by proper scientific control. But when the planters began to look for chemists and engineers, they were simply not to be obtained. $U_{p}$ to that time, the cane sugar industry throughout the whole world had been carried on largely by rule of thumb. Few men scientifically trained in sugar chemistry were to be found outside of Europe. In 1890 , therefore, at a meeting of the Louisiana Sugar Planters' Association, it was decided to establish, in connection with the Sugar Experiment Station, a school for the training of experts in sugar work. This was placed under the direction of Dr. Stubbs and was opened in I89I as the Audubon Sugar School. So far as I know, this was the first instance in America in which any industry established both laboratories for the scientific investigation of its problems and a school for the college training of men to put the theory into practice.

\section{POST-GRADUATE CHARACTER OF WORK}

As first outlined, the Audubon Sugar School was intended to appeal mainly to graduates of schools of engineering, and the course was distinctly post-graduate in character. The faculty was composed of some of the ablest men in the country, special stress being laid on research work. It soon became evident, however, that the number of college graduates who appreciated the opportunities in the sugar industry was quite small, and that the demand for training came mainly from men who had not received very much undergraduate training. Moreover, there were a number of applicants from tropical countries, whose preliminary studies had been of such a type as to make it impossible for them to take up, successfully, the advanced 